\title{
ARTICLE
}

\section{High performance direct borohydride fuel cell using bipolar interfaces and noble metal-free $\mathrm{Ni}$-based anodes}

Received 00th January 20xx, Accepted 00th January 20xx DOI: $10.1039 / x 0 x \times 00000 x$

Guillaume Braesch ${ }^{1,2}{ }^{*}$, Zhongyang Wang $^{3}$, Shrihari Sankarasubramanian ${ }^{4}$. Alexandr G. Oshchepkov ${ }^{2,5}$, Antoine Bonnefont ${ }^{6}$, Elena R. Savinova ${ }^{2}$, Vijay Ramani ${ }^{4}$, Marian Chatenet ${ }^{1}{ }^{*}$

\begin{abstract}
Due to its unmatched theoretical voltage of $2.18 \mathrm{~V}$, direct alkaline fuel cell using sodium borohydride solution at the anode and hydrogen peroxide at the cathode, represents a promising power source for high energy density applications. However, its development faces several challenges. Here we demonstrate a $\mathrm{BH}_{4}^{-1} / \mathrm{H}_{2} \mathrm{O}_{2}$ direct borohydride fuel cell (DBFC) with a platinum group metal (PGM)-free anode, which delivers unprecedented combination of $2.0 \mathrm{~V}$ open-circuit voltage and peak power density of $446 \mathrm{~mW} \mathrm{~cm}{ }^{-2}$. This exceptionally high cell voltage is enabled by combining a $\mathrm{pH}$-gradient-enabled microscale bipolar interface (PMBI), a Ni anode obtained by electrodeposition of Ni nanoparticles on an electrochemicallyetched $\mathrm{Ni}$ felt (eNFT), and a specially-designed simple but efficient coating procedure to deposit anion-exchange ionomer on the anode surface. The PMBI efficiently separates the drastically-disparate $\mathrm{pH}$ of the anolyte and the catholyte, the $\mathrm{Ni}_{E D} / \mathrm{eNFT}$ anode provides high surface area for efficient electrocatalysis and open porosity for fast mass-transport, while the coating procedure allows preserving $\mathrm{Ni}$ in metallic state, the latter being prerequisite for high anode performance. This work details how such fully nickel-based anodes are obtained and demonstrates why their BOR activity and stability outperforms that of PGM-based anodes.
\end{abstract}

KEYWORDS. Borohydride Oxidation Reaction (BOR), Direct Borohydride Fuel Cell (DBFC), Alkaline Fuel Cell (AFC), PGM-free anode, Bipolar interface, Hydrogen peroxide.

\section{Introduction}

Sodium borohydride $\left(\mathrm{NaBH}_{4}\right)$ is investigated since twenty years as a fuel for alkaline fuel cells. ${ }^{1-8}$ Advantages of $\mathrm{NaBH}_{4}$ as a fuel are its ability to provide 8 electrons per $\mathrm{BH}_{4}^{-}$anion (if fully oxidized in the Borohydride Oxidation Reaction, BOR, Equation 1), and its low standard potential translating in the high theoretical cell voltage of $1.64 \mathrm{~V}$ when $\mathrm{O}_{2}$ is used as an oxidant. The latter exceeds the theoretical voltage of a Proton Exchange Membrane Fuel Cell (PEMFC, the present state-of-the-art system) by $0.41 \mathrm{~V}$, making

${ }_{1}$ University Grenoble Alpes, University Savoie Mont Blanc, CNRS, Grenoble INP (Institute of Engineering and management, University Grenoble Alpes), LEPMI, 38000 Grenoble, France

2 Institut de Chimie et Procédés pour l'Energie, l'Environnement et la Santé, UMR 7515 CNRS-University of Strasbourg, 67087 Strasbourg Cedex, France

${ }^{3}$ Pritzker School of Molecular Engineering, University of Chicago, Chicago, IL 60637, USA

4 Center for Solar Energy and Energy Storage and Department of Energy, Environmental and Chemical Engineering, McKelvey School of Engineering, Washington University in St. Louis, St. Louis, MO, USA.

${ }^{5}$ Boreskov Institute of Catalysis, 630090 Novosibirsk, Russia

${ }^{6}$ Institut de Chimie de Strasbourg, UMR 7177 CNRS-University of Strasbourg, 67070 Strasbourg, Francet Footnotes relating to the title and/or authors should appear here.

* Correspondence and material requests should be addressed to Marian Chatenet (Marian.Chatenet@grenoble-inp.fr) and Guillaume Braesch (Guillaume.Braesch@lepmi.grenoble-inp.fr).

Electronic Supplementary Information (ESI) available: [details of any supplementary information available should be included here]. See DOI: 10.1039/x0xx00000x
Direct Borohydride Fuel Cell (DBFC), a promising technology for highenergy applications:

$$
\begin{gathered}
\mathrm{BH}_{4}^{-}+8 \mathrm{OH}^{-} \rightarrow \mathrm{BO}_{2}^{-}+6 \mathrm{H}_{2} \mathrm{O}+8 \mathrm{e}^{-} \\
\left(E^{0}=-0.414 \mathrm{~V} \text { vs reversible hydrogen electrode, } \mathrm{RHE}\right)
\end{gathered}
$$

Besides, $\mathrm{NaBH}_{4}$ is easily stored and transported in solid form and can be fed as liquid alkaline anolyte, ensuring safety of usage without compromising the high energy-density of the fuel. In the meantime, feeding $\mathrm{H}_{2}$ in PEMFCs involves multiple technical difficulties of production, purification, compression, transport, not to speak of the safety and cost of these processes. Furthermore, hydrogen peroxide $\left(\mathrm{H}_{2} \mathrm{O}_{2}\right)$ can be used as an oxidant, leading to a fully-liquid-fed system, the so-called $\mathrm{BH}_{4}^{-} / \mathrm{H}_{2} \mathrm{O}_{2}$ DBFC ${ }^{3,9-12}$ with its unmatched theoretical 
voltage of $2.18 \mathrm{~V}^{1}{ }^{1}$ These attractive features make the $\mathrm{BH}_{4}-/ \mathrm{H}_{2} \mathrm{O}_{2}$ $\mathrm{DBFC}$ an ideal technology for portable and mobile applications, e.g. in confined situations (such as submarines) where the use of $\mathrm{H}_{2}$ may be dangerous. However, despite exceptional promises of the $\mathrm{BH}_{4}$ $/ \mathrm{H}_{2} \mathrm{O}_{2}$ DBFC, practical implementation of such systems has not been achieved yet, essentially because of two hurdles.

The first obstacle is related to the difficulty in maintaining grossly different $\mathrm{pH}$ at the cathode fed with acidic $\mathrm{H}_{2} \mathrm{O}_{2}$ (the latter only being stable at low $\mathrm{pH}$ ) and the anode fed with alkaline $\mathrm{NaBH}_{4}$ solution $\left(\mathrm{BH}_{4}^{-}\right.$anions only being stable at high $\left.\mathrm{pH}^{13,14}\right)$. Continuous operation requires maintaining the $\mathrm{pH}$ of both the catholyte and anolyte close to their original values ( $c a .0$ and 14 , respectively) to avoid compromising the DBFC performance. Neither cation-exchange membranes (CEM) nor anion-exchange membranes (AEM) ${ }^{15-19}$, which are used in DBFCs, are capable to maintain such $\mathrm{pH}$ gradient between the two electrodes. Bipolar interfaces (BI) developed for various application targets ${ }^{20-23}$ seem to offer significant advantages for $\mathrm{BH}_{4}{ }^{-} / \mathrm{H}_{2} \mathrm{O}_{2}$ DBFCs. ${ }^{24-26}$ Some of us ${ }^{19}$ have recently been able to significantly increase the open circuit voltage (OCV) of the $\mathrm{BH}_{4}^{-} / \mathrm{H}_{2} \mathrm{O}_{2}$ DBFC by creating a "pH-gradient microscale bipolar interface $(\mathrm{PMBI})$ "27 that allows to maintain the $\mathrm{pH}$ gradient between the two electrodes. This enabled reaching a large peak power density of 300 $\mathrm{mW} . \mathrm{cm}^{-2}$ and high OCV of $1.8 \mathrm{~V}$ for a $5 \mathrm{~cm}^{2}$ unit $\mathrm{BH}_{4}-/ \mathrm{H}_{2} \mathrm{O}_{2}$ DBFC with a Pd anode. Note however that the achieved OCV was still largely inferior to the theoretical OCV of $2.18 \mathrm{~V}$.

The second obstacle, which hinders achieving high OCV and hence high energy density, is related to the utilization of PGMs at the DBFC anode. Known for their high hydrogen evolution reaction (HER) activity, PGMs prevent anode potential to extend below $0 \mathrm{~V}$ vs RHE, where the HER competes with the BOR. As a result, from 20 to $30 \%$ (depending on the oxidant used) of the theoretical cell voltage is lost with PGM-based electrocatalysts, not to mention their poor availability and high price ${ }^{28}$.

In this work we demonstrate unprecedented $\mathrm{BH}_{4}^{-} / \mathrm{H}_{2} \mathrm{O}_{2}$ DBFC performance, namely $\mathrm{OCV}$ reaching $2.0 \mathrm{~V}$ and peak power density of ca. $450 \mathrm{~mW} . \mathrm{cm}^{-2}$, by combining a Ni-based anode and a pH-gradientenabled microscale bipolar interface. In order to do so, we develop a highly-efficient stand-alone 3D-shaped and surface-controlled $\mathrm{Ni}$ based anode by electrodepositing $\mathrm{Ni}$ on an etched $\mathrm{Ni}$ felt with open porosity. We demonstrate that such an anode greatly outperforms either $\mathrm{Ni}$ catalysts prepared by conventional wet chemistry methods, or noble metal-based state-of-the-art catalyst materials. Electrodeposition, contrary to wet chemical methods, allows avoiding the passivation step, the latter resulting in oxidation of the Ni surface and ultimately to the BOR activity loss. We further design a PMBI preparation procedure, which allows preserving the surface of the $\mathrm{Ni}$ anode in an essentially metallic state, a determining factor allowing high BOR activity and high OCV. ${ }^{29}$ Indeed, Ni had long been tested for the BOR, the reported activity oscillating between low ${ }^{30-32}$ and high values ${ }^{33-35}$, until some of us demonstrated that these drastic differences of the observed activity originated from a poorlycontrolled state-of-surface of the catalyst, as detailed in 29,36-38. When nickel is covered by an oxide layer, both its HER and BOR activity are vanishingly-low. However, if the state of the surface is controlled and maintained metallic, the BOR activity increases, while the HER activity remains small, resulting in a record-low onset potential $\left(-0.25 \mathrm{~V}\right.$ vs $\mathrm{RHE}$, for $\left.\left[\mathrm{NaBH}_{4}\right]=5 \mathrm{mM}\right)$. In the meantime, the BOR kinetics is very fast on metallic nickel: the diffusion-limited current is reached below $0 \mathrm{~V}$ vs $\mathrm{RHE}^{29}$, at a potential where PGM anodes still struggle to initiate the reaction (they promote fast HER, this negative current overwhelming any anodic BOR contribution in this potential region). Besides high $\mathrm{Ni}$ surface area and metallic surface state, an efficient DBFC anode must have sufficiently large and open pores to ensure efficient mass-transport of reactants and products and optimize the residence time ${ }^{39}$. We build on recent publication of Braesch et al. ${ }^{40}$ to clean NFT from Ni oxides by acid etching ( $\mathrm{AE}$ ) and then modify its surface by Ni electrodeposition (ED). Finally, a unit $\mathrm{BH}_{4}-/ \mathrm{H}_{2} \mathrm{O}_{2}$ DBFC is assembled using these components, whose performance surpass all previous art, reaching record-high open-circuit voltage (2 V) and peak power density $\left(446 \mathrm{~mW} . \mathrm{cm}^{-2}\right)$ for a $5 \mathrm{~cm}^{2}$ cell.

\section{Experimental}

The detailed methods for preparing the Ni-based anode and the AEI can be found in Ref. ${ }^{40}$ and Refs. ${ }^{19,27}$, respectively.

\footnotetext{
${ }^{1}$ The value calculated taking into account the unavoidable junction potential between the acidic anode and alkaline cathode compartments. ${ }^{58}$
} 
Nickel-Felt characterization. The support used for the $\mathrm{Ni}_{\mathrm{ED}} / \mathrm{eNFT}$ anodes is a commercial NFT from Sorapec ${ }^{\circledR}$ composed of randomlydispersed polycrystalline $\mathrm{Ni}$ wires ( $20 \mu \mathrm{m}$ thick) forming a $500 \mu \mathrm{m}$ thick felt. The X-Ray Energy-Dispersive Spectra (XEDS) (EDAX ${ }^{\circledR}$ OCTANE ELITE 25) of the initial NFT and X-Ray Diffraction (XRD) diagrams (Bruker ${ }^{\circledR}$ D8 ADVANCE Diffractometer) of the NFT can be found in electronic supporting information (Figure $\mathrm{SI} 1$ and Figure $\mathrm{SI}$ 2 , respectively). The felt was imaged by SEM (Zeiss ${ }^{\circledR}$ Gemini SEM-500 operating at 15 or $3 \mathrm{kV}$ ) in both Secondary Electron (SE) and BackScattered Electron (BSE) mode at each step of the elaboration procedure of the SEBS/NiED/eNFT electrodes.

Half-cell measurements. All the electrochemical characterisations were performed in a homemade gas-tight three-electrode glass-cell using either a Biologic VMP-2 or a Gamry REF 600 potentiostat. A 1 $\mathrm{M} \mathrm{NaOH}$ solution prepared from $\mathrm{NaOH}$ crystals $(99.999 \%$ purity, Merck Suprapur $\left.{ }^{\oplus}\right)$ dissolved in ultra-pure water $(18.2 \mathrm{M} \Omega,<3 \mathrm{ppb}$ total organic carbon, MilliQ-gradient + Elix, Millipore ${ }^{\circledR}$ ) was used as supporting electrolyte and contained in a PTFE beaker inserted in the glass-cell to avoid contamination of the solution by silicates or other impurities ${ }^{41}$. A homemade Reversible Hydrogen Electrode (RHE) freshly-prepared prior each measurement was used as reference electrode and a Pt mesh as the counter-electrode. For the comparative tests (Figure 2) the working electrode was a Glassy Carbon (GC) electrode tip connected to a Rotating Disk Electrode (RDE) (Origatrode ${ }^{\circ}$, Origalys). The commercial carbon-supported nanoparticles (NPs/C, Premetek ${ }^{\circledR}$ ) catalysts were all dispersed in isopropanol, water and Nafion to form an ink. A drop of this ink was then deposited on the GC surface to form a thin layer of catalyst with a loading of $40 \mathrm{wt} . \%$. All samples were conditioned in supporting electrolyte by 10 cycles at $100 \mathrm{mV} . \mathrm{s}^{-1}$ followed by 3 cycles in the same potential range at $20 \mathrm{mV} . \mathrm{s}^{-1}$ in order to remove possible impurities. The potential range of the conditioning step did depend on the catalysts: $-0.2 ; 0.4 \mathrm{~V}$ vs RHE for Ni-based samples and $-0.2 ; 1.3 \mathrm{~V}$ vs RHE for PGM samples. To test the BOR activity of each catalyst, 50 $\mathrm{mM}$ of $\mathrm{NaBH}_{4}\left(98+\% \mathrm{Merck}^{\circledR}\right)$ was added to the $1 \mathrm{M} \mathrm{NaOH}$ solution. The solutions were purged by either $\operatorname{Ar}$ (99.999\% purity) or $\mathrm{N}_{2}$ (99.999\% purity) and CVs were performed in the low potential range $\left(-0.2 \rightarrow 0.3 \mathrm{~V}\right.$ vs RHE) at $20 \mathrm{mV} . \mathrm{s}^{-1}$ at room temperature $\left(T=20^{\circ} \mathrm{C}\right)$ and a rotation rate of the RDE of $1600 \mathrm{rpm}$.

The NFT electrodes were characterized in their initial state and after $90 \mathrm{~s}$ of $\mathrm{AE}$ without agitation in a mixture of strong acid: $50 \%$ of $\mathrm{CH}_{3} \mathrm{COOH}$ (glacial, Carl Roth ${ }^{\circledast}$ ), 30\% $\mathrm{HNO}_{3}\left(>65 \%\right.$, Carl Roth ${ }^{\circledR}$ ), $10 \%$ $\mathrm{H}_{2} \mathrm{SO}_{4}\left(96 \%\right.$, Carl Roth $\left.{ }^{\circledR}\right), 10 \% \mathrm{H}_{3} \mathrm{PO}_{4}\left(>85 \%\right.$, Sigma Aldrich $\left.{ }^{\circledR}\right)$. This solution was found efficient to remove the top layer of Nickel foams by Grdeń et al. ${ }^{42,43}$.

Ni NPs ED was performed in a separate electrochemical cell of the same design, where a solution of $0.01 \mathrm{M}$ (for electrodeposition on the $0.196 \mathrm{~cm}_{\text {geo }}{ }^{2} \mathrm{RDE}$ electrodes) or $0.1 \mathrm{M}$ (for $5 \mathrm{~cm}_{\text {geo }}^{2} \mathrm{DBFC}$ anodes) $\mathrm{NiSO}_{4} \bullet 6 \mathrm{H}_{2} \mathrm{O}$ (99.97\%, Alfa Aesar) + $0.1 \mathrm{M}\left(\mathrm{NH}_{4}\right)_{2} \mathrm{SO}_{4}$ (99+\%, Alfa Aesar) was used as the electrodeposition bath. The ED procedure is described in details in $\operatorname{Refs}^{29,40}$.
Preparation of the SEBS55 polymer and deposition on Ni-based anodes. The preparation of the SEBS55 polymer has been reported in Refs ${ }^{19,27}$. The solution of chloromethylated SEBS55 (55:45 molar ratio of styrene to rubber) in chlorobenzene was used to coat the $\mathrm{Ni}_{\mathrm{ED}} / \mathrm{eNFT}$ anodes by two methods. The first one is directly adapted from the coating technique used by Wang et al. ${ }^{27}$ and consists of spraying the SEBS solution directly onto the previously-prepared $\mathrm{Ni}_{\mathrm{ED}} / \mathrm{eNFT}$ electrode using an air brush (Badger model 150) fed by nitrogen ( $\mathrm{N}_{2}, 99.999 \%$ purity). The sample is placed on a heating plate $\left(70^{\circ} \mathrm{C}\right)$ to evaporate remaining water present in the thickness of the felt and also to evaporate the chlorobenzene, producing a layer of SEBS-55 on the $\mathrm{Ni}_{E D} \mathrm{NPs}$. Once the polymer sprayed on the surface, the sample was immersed in a solution of 1-methyl-2pyrrolidinone (NMP) (20 mL) and TMA (31-35 wt\% in ethanol) $(5 \mathrm{~mL})$ at $50^{\circ} \mathrm{C}$ for 24 hours to functionalize it and yield the AEI (SEBS55TMA). The second method consists of immersing the prepared $\mathrm{Ni}_{\mathrm{ED}} / \mathrm{eNFT}$ electrode in the solution of chloromethylated SEBS55 + chlorobenzene for $10 \mathrm{~min}$. The chlorobenzene has to be removed from the pores prior to the functionalization step in NMP + TMA. To that goal, a drying step of $1 \mathrm{~h}$ in a vacuum oven at $60^{\circ} \mathrm{C}$ has been added after the immersion. The vacuum is mandatory in order to avoid heating the metallic $\mathrm{Ni}$ electrode in presence of $\mathrm{O}_{2}$ and therefore to avoid its irreversible oxidation. Once the sample is dry, the same functionalization step described previously is performed. Prior to the installation of the anode in the cell, it is cleaned with deionized water and then immersed in $1 \mathrm{M} \mathrm{KOH}$ for $1 \mathrm{~h}$ at room temperature to replace the $\mathrm{Cl}^{-}$moieties by $\mathrm{OH}^{-}$.

DBFC $\left(\mathrm{BH}_{4}-/ \mathrm{H}_{2} \mathrm{O}_{2}\right)$ tests. The DBFC measurements were performed at $70^{\circ} \mathrm{C}$ in a corrosion-resistant cell (Fuel Cell Technologies, Inc.) composed of squared $5 \mathrm{~cm}^{2}$ electrodes $(2.24 \times 2.24 \mathrm{~cm})$ with interdigitated canals. The optimum temperature of $T=70^{\circ} \mathrm{C}$ was chosen as it resulted in the best balance between DBFC performance and minimization of unwanted side reactions (optimization data presented in Figure $\mathrm{SI} 3$ ). The anodes used were the $\mathrm{Ni}_{\mathrm{ED}} / \mathrm{eNFT}+\mathrm{AEI}$ samples described above and the cathode was made of a carbonsupported Pt catalyst (46 wt\% Pt/C from Tanaka K. K.) sprayed on porous carbon paper (GDL 24AA diffusion media from lon Power) resulting in a catalyst loading of $1 \mathrm{mg} \cdot \mathrm{cm}^{-2}$. A commercial Nafion-117 (175 $\mu \mathrm{m}$ thick) membrane was used to separate the two electrodes and ensure $\mathrm{H}^{+}$conduction. The anolyte was made of $3 \mathrm{M} \mathrm{KOH}+1.5$ $\mathrm{M} \mathrm{NaBH}_{4}$ and the catholyte of 15 wt\% $\mathrm{H}_{2} \mathrm{O}_{2}$ in $1.5 \mathrm{M} \mathrm{H}_{2} \mathrm{SO}_{4}$ and both were flowed through the cell using peristaltic pumps with a flow rate of $5 \mathrm{~mL} \cdot \mathrm{min}^{-1}$. The flowrate has also been previously optimized ${ }^{44}$ The measurements were performed using a Solartron ${ }^{\circledR}$ potentiostat with a $4 \mathrm{~A}$ limitation. $0.1 \mathrm{~V}$ decreasing steps were applied and maintained for $2 \mathrm{~min}$ from the OCV value to $0.05 \mathrm{~V}$ or until the current limitation was reached. In the initial tests, a $200 \mu \mathrm{m}$-thick seal was used at the anode, therefore compressing it by $150 \%$ and non-negligibly limiting mass-transport in the electrode. Further tests were performed with a $400 \mu \mathrm{m}$-thick seal compressing the anode by $25 \%$ and allowing a much better transport of the electrolytes in the pores. 


\section{Results and discussion}

Preparation procedure of enhanced Ni-felts (NFT). The NFT was chosen as the electrode support in order to (i) avoid the use of carbon, the latter leading to durability issues when used in alkaline medium ${ }^{45-47}$, (ii) increase the overall electronic conductivity of the electrode, but most importantly (iii) provide a better fuel management thanks to its high porosity, one of the key factors for a high-performance DBFC anode ${ }^{39}$. The NFT in its pristine state is illsuited for a DBFC anode. The elaboration procedure to obtain a highperformance anode is detailed in Ref. ${ }^{40}$ and Figure 1 summarizes the state of the NFT after each of the electrode elaboration step. The cyclic voltammogram (CV, Figure 1.A) shows the electrochemical signature of the electrode in supporting electrolyte. Cyclic voltammetry is a facile in situ tool, which allows not only to probe the state of the Ni surface (metallic versus oxide-covered), but also to quantify the amount of metallic sites available on the surface, and to determine the available Electrochemical Surface Area (ECSA) of metallic $\mathrm{Ni}^{2}{ }^{2}$ This is conveniently done by integrating the CV peak observed around $0.3 \mathrm{~V}$ vs RHE and corresponding to the transition between $\mathrm{Ni}$ and surface $\alpha-\mathrm{Ni}(\mathrm{OH})_{2} \cdot{ }^{29,40,48}$ For a pristine NFT, no peak is observed at $0.3 \mathrm{~V}$, a sign of strongly-oxidized surface (either resulting from the NFT manufacturing or ambient storage). This translates into poor BOR activity (Figure 1.B) as explained in Ref. ${ }^{29} \mathrm{AE}$ of the NFT in a mixture of strong acids (described by Grden et al. ${ }^{42,43}$ ) aimed to remove the oxidized layers and efficiently reveals the underneath metallic sites: SEM images of the etched-NFT (eNFT) show a rougher surface, demonstrating that nickel oxides were (at least partially) removed/dissolved. The CV of Figure 1.A reveals an increased double layer capacitance and the emergence of a peak at $0.3 \mathrm{~V}$ vs RHE, which confirms the presence of metallic nickel sites on the surface; as a result, the BOR activity increases (Figure 1.B). This BOR activity is however still not sufficiently high for the DBFC, because the amount of active sites is limited by the surface of the NFT. Further increasing the NFT roughness by AE would lead to excessive nickel fibre thinning, degradation of the felt mechanical strength, and failure of the anode material's integrity. To substantially increase the number of active sites, the best option is to perform an ED of Ni NPs. The procedure was developed by some of us $29,36,49$ and adapted to the eNFT ( $\mathrm{Ni}_{\mathrm{ED}} / \mathrm{eNFT}$ ). The SEM images of Figure 1 present the resulting surface, where $\mathrm{Ni}$-agglomerates can now be observed. Ni-electrodeposition on the NFT results in 8.5 -fold increase of the number of metallic surface sites (ECSA of $1942 \mathrm{~cm}^{2}$ after the $\mathrm{Ni}_{E D}$ against $227 \mathrm{~cm}^{2}$ before the $\mathrm{ED}$ ), which translates in very fast BOR kinetics and low onset-potential (-220 mV vs RHE). The amount of electrodeposited $\mathrm{Ni}$ cannot be calculated from the deposition charge, because of the $\mathrm{H}_{2}$ formation (through HER) occurring simultaneously to the $\mathrm{Ni}^{2+}$ reduction at the deposition potential. Whereas the nickel-loading of the $\mathrm{Ni}_{\mathrm{ED}} / \mathrm{C}$ could be measured using ICP-MS analyses ${ }^{29}$, this method cannot be applied to the $\mathrm{Ni}_{\mathrm{ED}}$ /eNFT samples (because of the NFT). However, using the ECSA values, the loading of the $1942 \mathrm{~cm}^{2} \mathrm{Ni}_{\mathrm{ED}} / \mathrm{eNFT}$ electrode was estimated as $1.2 \mathrm{mg}_{\mathrm{Ni}, \mathrm{ED} . \mathrm{cm}^{-2}}$

\footnotetext{
2 Note that the information provided by CV regarding the surface state of $\mathrm{Ni}$ and the number of metallic $\mathrm{Ni}$ sites is much more precise than that offered by ex situ X-ray photoelectron spectroscopy.
} 


\section{ARTICLE}

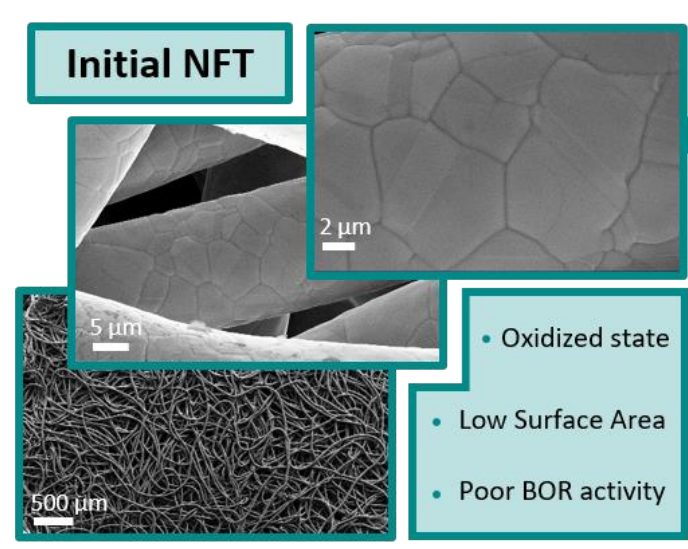

E (V vs RHE)

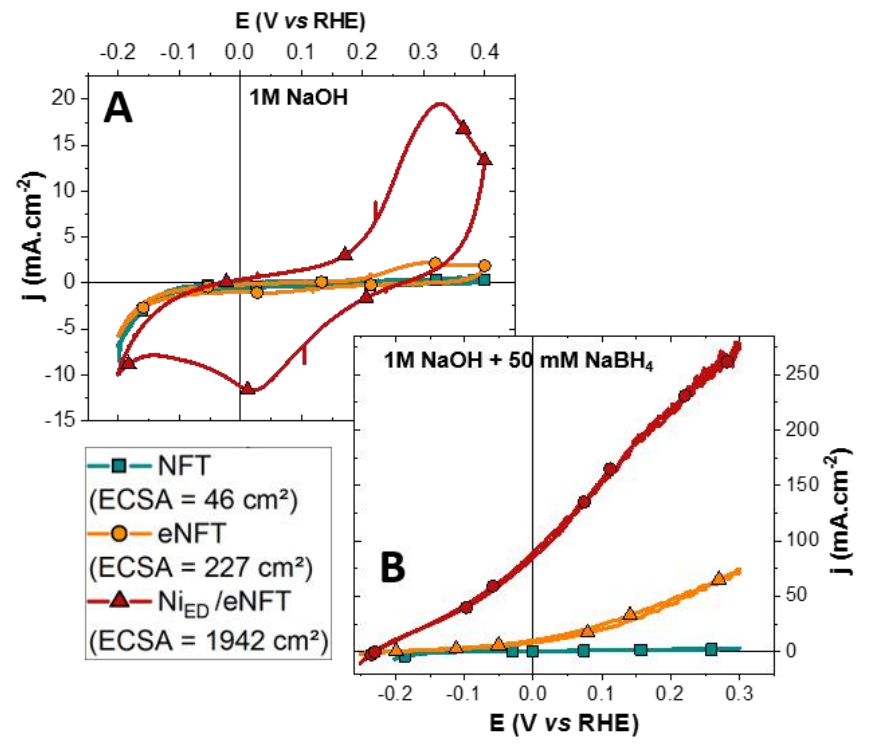

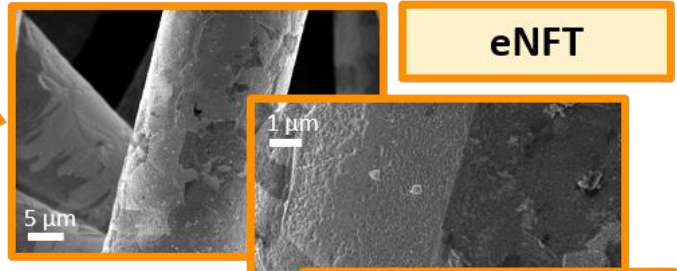

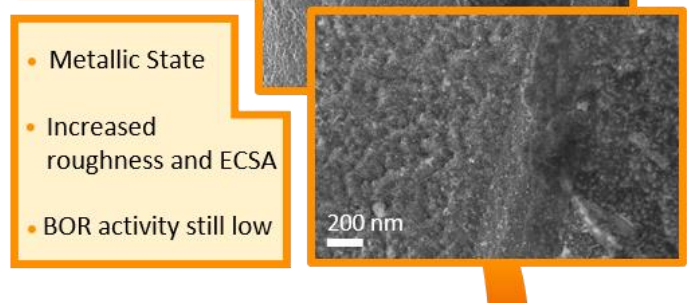

Nickel Electrodeposition

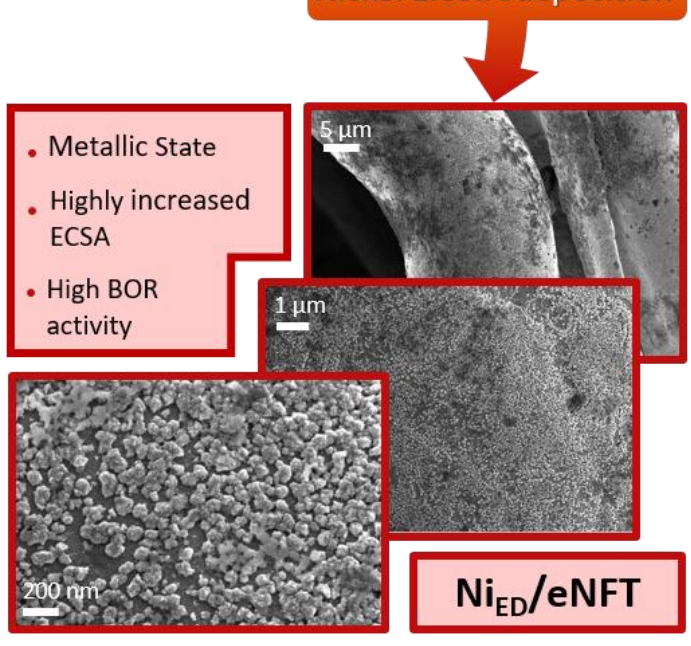

Figure 1. Evolution of the morphology, electrochemical surface area (ECSA), and BOR activity following consecutive steps of the electrode elaboration process. The oxidation state and the amount of active sites is tuned through a two-steps process: (i) an acid etching of the initial NFT to reveal metallic sites and increase the roughness (ii) and an electrodeposition of Ni NPs to highly increase the number of active sites and the BOR activity, as demonstrated by voltamograms both in $(A)$ supporting electrolyte $(1 \mathrm{M} \mathrm{NaOH})$ and in $(B) B O R$ conditions $(1 \mathrm{M} \mathrm{NaOH}$ $\left.+50 \mathrm{mM} \mathrm{NaBH}_{4}\right)$. CV conditions: Ar-saturated solutions, $T=20^{\circ} \mathrm{C}, v_{\mathrm{s}}=20 \mathrm{mV} \cdot \mathrm{s}^{-1}, \omega=1600 \mathrm{rpm}$.

Comparison of $\mathrm{Ni}_{\mathrm{ED}} / \mathrm{eNFT}$ anodes with state-of-the-art BOR catalysts. In order to benchmark the outstanding BOR activity of the so-obtained $\mathrm{Ni}_{\mathrm{ED}} / \mathrm{eNFT}$ anodes, they were tested in a half-cell configuration in both potentio-dynamic and potentio-static conditions and compared to other $\mathrm{Ni}$-based catalysts: $\mathrm{Ni}_{\mathrm{ED}} / \mathrm{C}$ from Ref. ${ }^{29}$ and Ni/C NPs (provided by Prof. Deckel's group ${ }^{50}$ and obtained through wet chemical synthesis followed by relevant heattreatments to first reduce $\mathrm{Ni}^{2+}$ and then passivate the ensuing $\mathrm{Ni}$ nanoparticles); PGM catalysts (commercial Pt/C, Pd/C) and Au/C NPs, the most commonly-used electrocatalysts for the BOR, were also tested for comparison. The potentio-dynamic measurement (Figure
2.A) highlights the low onset potential of $\mathrm{Ni}$ electrodeposited either on carbon or $\mathrm{Ni}$ felt, while representative potentio-static measurements (Figure 2.B) demonstrate the stability of the current at a given potential. Pt is still the most used BOR catalyst, owing to the high current densities obtained at its surface, albeit at potential values above $0 \mathrm{~V} v$ v RHE. However, this current (at least partly) comes from the indirect oxidation of the $\mathrm{H}_{\mathrm{ad}}$ species formed on the $\mathrm{Pt}$ surface during the dissociative adsorption of $\mathrm{BH}_{4}{ }^{-51-53}$. In addition, the high activity of $\mathrm{Pt}$ towards hydrogen electrode reactions drags the mixed potential of a $\mathrm{NaBH}_{4}$-containing electrolyte towards the equilibrium hydrogen electrode potential ( $0 \mathrm{~V}$ vs. RHE), thus 
preventing the BOR onset potential to approach the thermodynamic value (the BOR onset on $\mathrm{Pt}$ is $-50 \mathrm{mV}$ vs RHE in $50 \mathrm{mM} \mathrm{NaBH}_{4}$, Figure 2.A). On the contrary, because of the poor HER activity of metallic $\mathrm{Ni}$, the $\mathrm{Ni}_{\mathrm{ED}} / \mathrm{C}$ catalyst shows a significantly-lower onset potential (-250 $\mathrm{mV}$ vs RHE in $50 \mathrm{mM} \mathrm{NaBH}_{4}$, Figure 2.A) and fast BOR kinetics, making of metallic-Ni the best BOR catalyst in the low potential region (the most practically-relevant region for a DBFC anode). While the $200 \mathrm{mV}$ OCV improvement has been reported in Refs. ${ }^{29,40}$, the limiting current on the $\mathrm{Ni}_{\mathrm{ED}} / \mathrm{C}$ electrode was inferior to that of $\mathrm{Pt} / \mathrm{C}$, resulting in an overall 4 electrons generated per $\mathrm{BH}_{4}{ }^{-}$species. The $\mathrm{Ni}_{\mathrm{ED}} / \mathrm{eNFT}$ electrode presents the same BOR activity at low potentials, owing to its metallic surface-state, but mass-transfer limitation (evident with $\mathrm{Ni}_{\mathrm{ED}} / \mathrm{C}$ ) is now less pronounced and the current density competes with $\mathrm{Pt} / \mathrm{C}$ until higher potential values. This shows that using a very open 3D NFT structure as the NPs support, enables better masstransfer and management of intermediate species ${ }^{40}$. The $\mathrm{Ni} / \mathrm{C}$ catalyst prepared by a conventional chemical synthesis (involving heat-treatments during the reduction step), followed by surface passivation of the Ni NPs ${ }^{50}$ shows higher onset potential, but most importantly much slower reaction kinetics. Indeed, the mandatory passivation step of the preparation procedure (otherwise the material is pyrophoric) and (inevitable) storage/transport under air (which can be avoided with the electrodeposition procedure), lead to highly-oxidized Ni NPs. This surface oxidation is hardly reversible: even after conditioning in supporting electrolyte and attempts to reduce the surface in strongly-reducing $\mathrm{BH}_{4}{ }^{-}$conditions (or at low electrode potentials), the samples cannot be activated. Both Pd/C and $\mathrm{Au} / \mathrm{C}$ show really poor performance towards the BOR in the low potential range. Potentio-static measurements shown in Figure $2 \mathrm{~B}$ are more relevant to the DBFC operation conditions. While the Pt/C electrode slightly outperforms $\mathrm{Ni}$ electrodes in terms of the initial current density at potential equal to or higher than $0.2 \mathrm{~V} v$ s RHE, a significant current drop is observed (more than $90 \%$ in 1 hour) when the potential is maintained at $0.2 \mathrm{~V}$ vs RHE (Figure 2.B). This effect, exacerbated at high $\mathrm{NaBH}_{4}$ concentration ${ }^{29}$, is explained by the selfpoisoning of the electrode by the BOR intermediate species ${ }^{54,55}$, which progressively block its active sites. Such poisoning is not observed on metallic Ni surfaces or at least to a much lesser extent, due to a weaker $\mathrm{BH}_{4}{ }^{-}$adsorption corroborated by DFT calculations ${ }^{29}$, suggesting that the BOR proceeds via a different reaction pathway generating less poisoning species. Thus, metallic Ni-based electrodes are more stable towards the BOR, a clear advantage for DBFC applications.
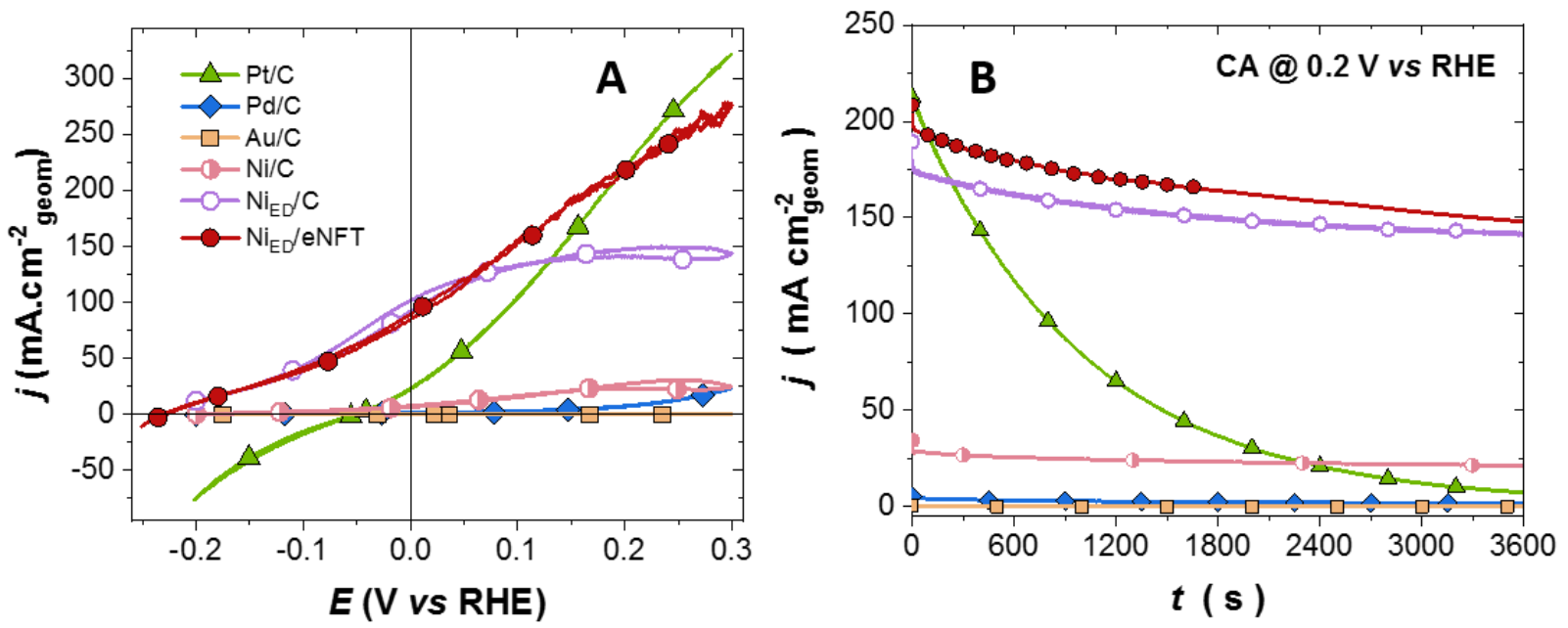

Figure 2. Comparison of the most commonly used catalysts for the BOR and the $\mathrm{Ni}_{E D}$-based electrodes in $1 \mathrm{M} \mathrm{NaOH}+50 \mathrm{mM} \mathrm{NaBH} 4(\mathrm{Ar}-$ saturated solution, $\left.T=20^{\circ} \mathrm{C}, \omega=1600 \mathrm{rpm}\right)$ in: (A) potentiodynamic conditions $\left(v_{s}=20 \mathrm{mV} \cdot \mathrm{s}^{-1}\right)$ showing the lower onset potential on $\mathrm{Ni}_{E D^{-}}$ based catalysts compared to PGMs and (B) potentiostatic conditions ( $E=0.2 \mathrm{~V}$ vs RHE) showing the better stability on $\mathrm{Ni}_{\mathrm{ED}}$-based catalysts. The metal loading for all electrodes is $40 \mu \mathrm{g} \cdot \mathrm{cm}^{-2}$.

Deposition of an anion exchange ionomer (AEI) on $\mathrm{Ni}_{\mathrm{ED}} / \mathrm{eNFT}$ anodes. Deposition of the AEI layer on the DBFC anode is an essential step in the elaboration of a $\mathrm{PMBI}^{27}$ the latter ensuring efficient separation of the alkaline anolyte and acidic catholyte. Considering the influence of the state of the Ni surface on its BOR activity, the challenge was to develop a deposition procedure ensuring uniform coating, while maintaining the reduced (metallic) state of the $\mathrm{Ni}_{\mathrm{ED}} / \mathrm{eNFT}$ anode. Several deposition procedures have been evaluated and compared. The spraying method (in what follows labelled with $\mathbf{S}$ ) was adapted from Wang et al ${ }^{27}$, where it was applied to a Pd/C DBFC anode. After the ED of Ni NPs, the sample was dried using absorbent paper and then placed on a heating plate $\left(70^{\circ} \mathrm{C}\right)$ and the SEBS55 polymer (see Refs. ${ }^{19,27}$ ) was sprayed directly on it, water being still present in the pores, and chlorobenzene solvent evaporated. After the coating, the SEBS55 was functionalized in NMP + TMA, yielding the AEI. The SEM images are presented on Figure 3 (red frame) together with the current-voltage characteristics and the power density. The electrodes were tested in DBFC conditions using a commercial Nafion- $117^{\circledR}$ membrane and a Pt/C (1 mg.cm-2) cathode for $\mathrm{H}_{2} \mathrm{O}_{2}$ reduction. 


\section{ARTICLE}

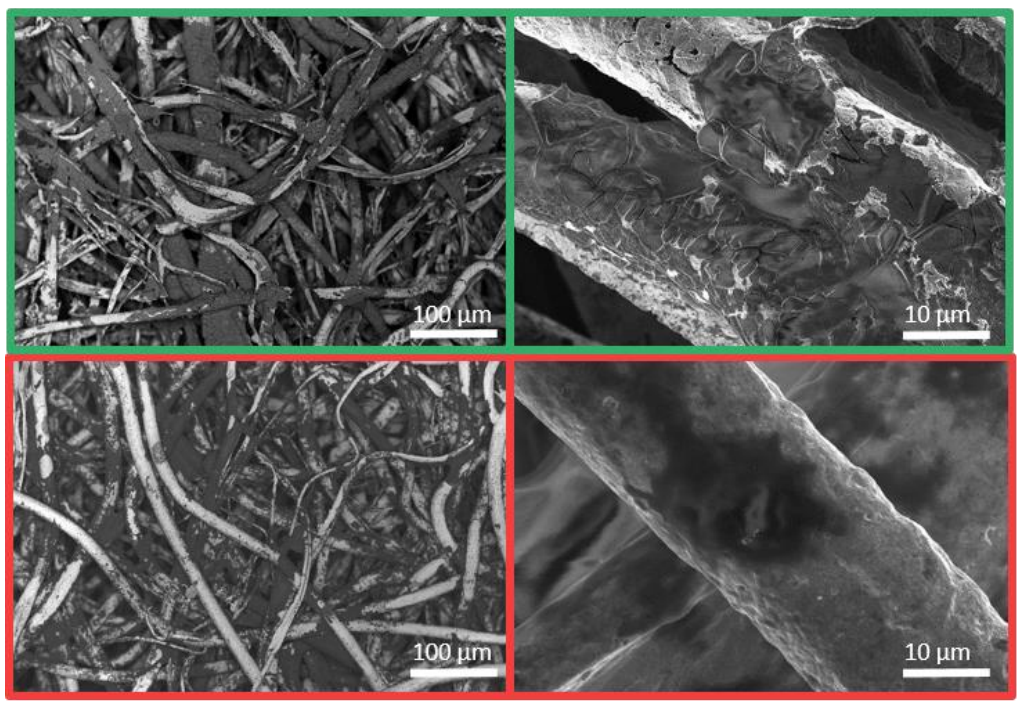

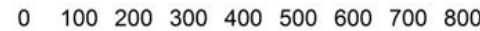

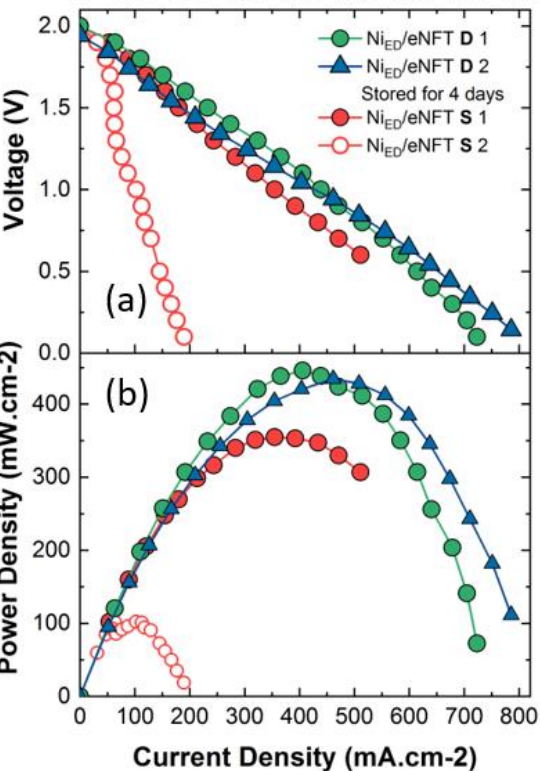

Figure 3. SEM images of the SEBS/Ni $\mathrm{ED}_{\mathrm{E}}$ eNFT electrodes prepared via either dipping (D) of the anode in SEBS-55 solution (green borders) or spraying (S) of the ionomer solution onto the electrode (red borders) at different magnification ( $x 200$ and $\times 5 \mathrm{k}$ ). Corresponding polarization (a) and power density (b) curves in DBFC conditions of the two preparation methods $\left(T=70^{\circ} \mathrm{C}\right.$, anolyte: $3 \mathrm{M} \mathrm{KOH}+1.5 \mathrm{M} \mathrm{NaBH}$, catholyte: $1.5 \mathrm{M} \mathrm{H}_{2} \mathrm{SO}_{4}+15 \mathrm{wt} \% \mathrm{H}_{2} \mathrm{O}_{2}$, flow rate: $0.4 \mathrm{~mL} \cdot \mathrm{min}^{-1} . \mathrm{cm}^{-2}$ ). The SEM images were acquired after DBFC measurements in which the anode was pressed against the membrane. The AEl layer directly in contact with it was therefore essentially removed from the anode when it was separated from the membrane. This explains why most of the outer nickel wires appears without the AEl layer, but the ionomer was most probably present before and during the DBFC tests.

The $\mathrm{Ni}_{\mathrm{ED}} / \mathrm{eNFT}-\mathrm{S} 1$ anode reached an impressive OCV of $2.0 \mathrm{~V}$ (red curve in Figure 3), where only $1.8 \mathrm{~V}$ was reached in the same conditions using $\mathrm{Pd} / \mathrm{C}$ anodes ${ }^{27}$. This corresponds to the $200 \mathrm{mV}$ improvement measured on metallic Ni surfaces compared to PGM catalysts during the half cell tests. Reaching this improvement firstly confirms the effectiveness of the PMBI to maintain the important $\mathrm{pH}$ gradient between the anode and the cathode (the slope of the polarisation plot is parallel to the one with $\mathrm{Pd} / \mathrm{C}$ from, ${ }^{27}$ where the film integrity was confirmed). Secondly, it means that the anode is indeed capable to oxidize the $\mathrm{BH}_{4}^{-}$at very low potential (lower than what $\mathrm{Pd}$ can do), hence that $\mathrm{Ni}$ is in its mostly-reduced state. The peak power density for the $\mathrm{Ni}_{\mathrm{ED}} / \mathrm{eNFT}-\mathrm{S} 1$ sample was achieved at 1.0 $\mathrm{V}$ and reached $355 \mathrm{~mW} \mathrm{~cm}^{-2}$. One must remember that spraying was performed in air at $T=70^{\circ} \mathrm{C}$, conditions where the surface of $\mathrm{Ni}$ nanoparticles might be partly-oxidized, so this performance is already outstanding. A second electrode was prepared in the exact similar conditions ( $\mathrm{Ni}_{\mathrm{ED}} / \mathrm{eNFT}-\mathrm{S} 2$ ) and the same OCV was reached, meaning that the state of surface of the anode is still metallic, in majority. However, this second test showed a disastrous peak power density $\left(P_{\max }=102 \mathrm{~mW} . \mathrm{cm}^{-2}\right.$ at $\left.1.0 \mathrm{~V}\right)$. This is attributed to a nonreproducibility in the spraying deposition method: (i) it is almost impossible to assert that the sprayed AEI layer fully penetrates the whole thickness of the $\mathrm{Ni}_{\mathrm{ED}} / \mathrm{eNFT}$, leaving uncoated $\mathrm{Ni}$ fibres for which the PMBI is not well-established and the Ni-metal state of surface might be locally-lost, while (ii) in some cases, fibres might be surrounded by thick pockets of AEI, thereby preventing masstransfer of reactant to the $\mathrm{Ni}$ catalytic sites, and inhibiting the necessary release of hydrogen bubbles formed in the bulk of the porous electrode. In order to solve this issue, another method, namely dipping (in what follows labelled as $\mathbf{D}$ ) was evaluated. To this end, the $\mathrm{Ni}_{\mathrm{ED}}$ /eNFT was simply dipped (at room temperature) in the solution of SEBS-55 in chlorobenzene after removing any excess of water (by gentle pressing of the electrode on an absorbent paper) to allow solvent penetration in the $\mathrm{Ni}_{\mathrm{ED}}$ /eNFT pores. Then, the AEl layer was dried for $1 \mathrm{~h}$ in a vacuum oven at $T=60^{\circ} \mathrm{C}$, vacuum (absence of $\mathrm{O}_{2}$ ) preventing irreversible oxidation of the $\mathrm{Ni}_{\mathrm{ED}} / \mathrm{eNFT}$. This strategy enables more homogeneous coating of the AEI in the whole $\mathrm{Ni}_{\mathrm{ED}} / \mathrm{eNFT}$ structure (which prevents the biases noted for the dipping method, above) while preserving the metallic state of the electrode as confirmed by the high OCV value. As such, the dipping procedure resulted in reproducible anodes, leading to OCV values of $2.0 \mathrm{~V}$ and a yet higher peak power density of ca. $450 \mathrm{mV} \mathrm{cm}^{-2}$. This confirms the 
importance of the AEI deposition procedure for the overall performance and suggests that the targeted metallic surface state of the $\mathrm{Ni}_{\mathrm{ED}} / \mathrm{eNFT}-\mathrm{D} 1$ electrode was indeed achieved. This method resulted in a more reproducible ionomer deposition as attested by the comparable performance obtained with both electrodes prepared this way (Figure 3), although the coating was not strictly homogenous on the entire surface. Moreover, this second electrode (Ni $\mathrm{ED}_{\mathrm{ED}} / \mathrm{eNFT}-\mathrm{D}$ 2) was stored in water for four days prior to the DBFC test. While exhibiting somewhat lower OCV (1.94 V, likely due to formation of some surface oxides on the Ni surface during the electrode storage), the latter shows comparable overall performance (blue curve), thus confirming that the developed approach is fullycompatible with practical applications, where exposure to air may be inevitable (a result of utmost importance). Previous publications. 27,56 demonstrated stability of PMBI under similar operating conditions.

Table 1. Comparison of recent DBFC performance data. "na" stand for non-available information.

\begin{tabular}{|c|c|c|c|c|c|c|c|}
\hline Ref & $\begin{array}{c}\text { Anode } \\
\text { (loading, } \mathrm{mg} \cdot \mathrm{cm}^{-2} \text { ) }\end{array}$ & $\begin{array}{c}\text { Cathode } \\
\text { (loading, mg.cm-2) }\end{array}$ & $\begin{array}{c}\text { Separator } \\
\text { (thickness, } \mu \mathrm{m} \text { ) }\end{array}$ & Oxidant & $\begin{array}{c}T \\
\left({ }^{\circ} \mathrm{C}\right)\end{array}$ & $\begin{array}{c}P_{\max } \\
\left(\mathrm{mW} \cdot \mathrm{cm}^{-2}\right)\end{array}$ & $\begin{array}{l}\text { OCV } \\
\text { (V) }\end{array}$ \\
\hline 39 & $\mathrm{Pt} / \mathrm{C}(0.5)$ & $\mathrm{Pt} / \mathrm{C}(2)$ & Nafion $212(50)$ & $\mathrm{O}_{2}$ & 60 & 420 & 0.94 \\
\hline 31 & $\mathrm{NiB} / \mathrm{C}(70)$ & $\mathrm{LaNi}_{0.9} \mathrm{Ru}_{0.1} \mathrm{O}_{3} / \mathrm{C}$ (7.5) & PEM (na) & $\mathrm{O}_{2}$ & 25 & 180 & 1.09 \\
\hline 57 & $\mathrm{Pd} / \mathrm{C}(0.3)$ & $\mathrm{Pt} / \mathrm{C}(0.3)$ & Nafion 117 (183) & $\mathrm{H}_{2} \mathrm{O}_{2}$ & 25 & 211 & 1.72 \\
\hline 57 & $\mathrm{Pt} / \mathrm{C}(0.3)$ & $\mathrm{Pt} / \mathrm{C}(0.3)$ & Nafion 117 (183) & $\mathrm{H}_{2} \mathrm{O}_{2}$ & 25 & 275 & 1.67 \\
\hline 29 & $\mathrm{Ni}_{\mathrm{ED}} / \mathrm{C}(0.6)$ & $\mathrm{Pt} / \mathrm{C}(2)$ & Nafion $212(50)$ & $\mathrm{O}_{2}$ & 60 & 108 & 1.21 \\
\hline 40 & $\mathrm{Pt} / \mathrm{C}(0.16)$ & $\mathrm{Pt} / \mathrm{C}(2)$ & Nafion $212(50)$ & $\mathrm{O}_{2}$ & 60 & 194 & 1.01 \\
\hline 40 & $\mathrm{Ni}_{\mathrm{ED}} / \mathrm{eNFT}(1.2)$ & $\mathrm{Pt} / \mathrm{C}(2)$ & Nafion $212(50)$ & $\mathrm{O}_{2}$ & 60 & 180 & 1.24 \\
\hline 27 & $\mathrm{Pd} / \mathrm{C}(1)+\mathrm{Ni}$ & $\mathrm{Pt} / \mathrm{C}(1)$ & Bipolar Interface (175) & $\mathrm{H}_{2} \mathrm{O}_{2}$ & 70 & 300 & 1.80 \\
\hline This work & $\mathrm{Ni}_{\mathrm{ED}} / \mathrm{eNFT}-\mathrm{D}(0.7)$ & $\mathrm{Pt} / \mathrm{C}(1)$ & Bipolar Interface (175) & $\mathrm{H}_{2} \mathrm{O}_{2}$ & 70 & 446 & 2.0 \\
\hline
\end{tabular}

Benchmarking the DBFC performance. The OCV (2.0 V) and peak power density $\left(446 \mathrm{~mW} . \mathrm{cm}^{-2}\right)$ reached with the $\mathrm{Ni}_{\mathrm{ED}} / \mathrm{eNFT}-\mathrm{D}$ anodes confirm the advantageous combination of the PMBI, the high-surface area 3D-open structure metallic $\mathrm{Ni}$ catalyst and the optimized AEI deposition procedure: this impressive result largely surpasses that of a PGM-based cell (with the same geometry and operating conditions), as displayed on Figure 4. Additional comparative values of peak power density and OCV with recently-published studies are listed in Table 1, corroborating the unprecedented performance of $\mathrm{BH}_{4}-1 \mathrm{H}_{2} \mathrm{O}_{2}$ DBFC achieved in this work using non-PGM anode catalysts. The improvement of $200 \mathrm{mV}$ on the OCV by using $\mathrm{Ni}$ electrodes (in their metallic state of surface) over Pt or Pd is clearly observed with either $\mathrm{O}_{2}$ or $\mathrm{H}_{2} \mathrm{O}_{2}$ oxidant. $\mathrm{Ni}$-based anodes perform better at high cell voltage in both conditions, and are tied (within the error bar) with $\mathrm{Pt}$ anodes combined with a CEM and $\mathrm{O}_{2}$ at the cathode. In addition, the power density drops more abruptly at high current density with $\mathrm{Pt} / \mathrm{C}$ than with $\mathrm{Ni}_{\mathrm{ED}} / \mathrm{eNFT}$, which can be associated with more efficient mass-transfer in the open porosity 3Dstructured NFT support than in "compact" carbon black-based active layers. Regarding the $\mathrm{PMBI}+\mathrm{H}_{2} \mathrm{O}_{2}$ results, polarization curves for $\mathrm{Ni}_{\mathrm{ED}} / \mathrm{eNFT}-\mathrm{D}$ and $\mathrm{Pd} / \mathrm{C}$ are rather parallel, signing the overall better catalytic performance of $\mathrm{Ni}_{\mathrm{ED}} / \mathrm{eNFT}$ versus $\mathrm{Pd} / \mathrm{C}$ (all other limitations, e.g. related to Ohmic drop and mass-transfer, being identical). The slope of the polarization curves for the PMBI cells is however steeper in these conditions. This is explained by the use of a significantly thicker $(175 \mu \mathrm{m})$ Nafion-117 membrane than the one used during the $\mathrm{O}_{2}$ tests (Nafion-212, $50 \mu \mathrm{m}$ ). While using thinner CEM would lower the cell resistance and therefore improve its performance, it could lead to larger risks of membrane perforation and of mixing of the strongly-reducing alkaline anolyte with a strongly-oxidizing acidic catholyte, adversely-affecting the durability of the cell. 


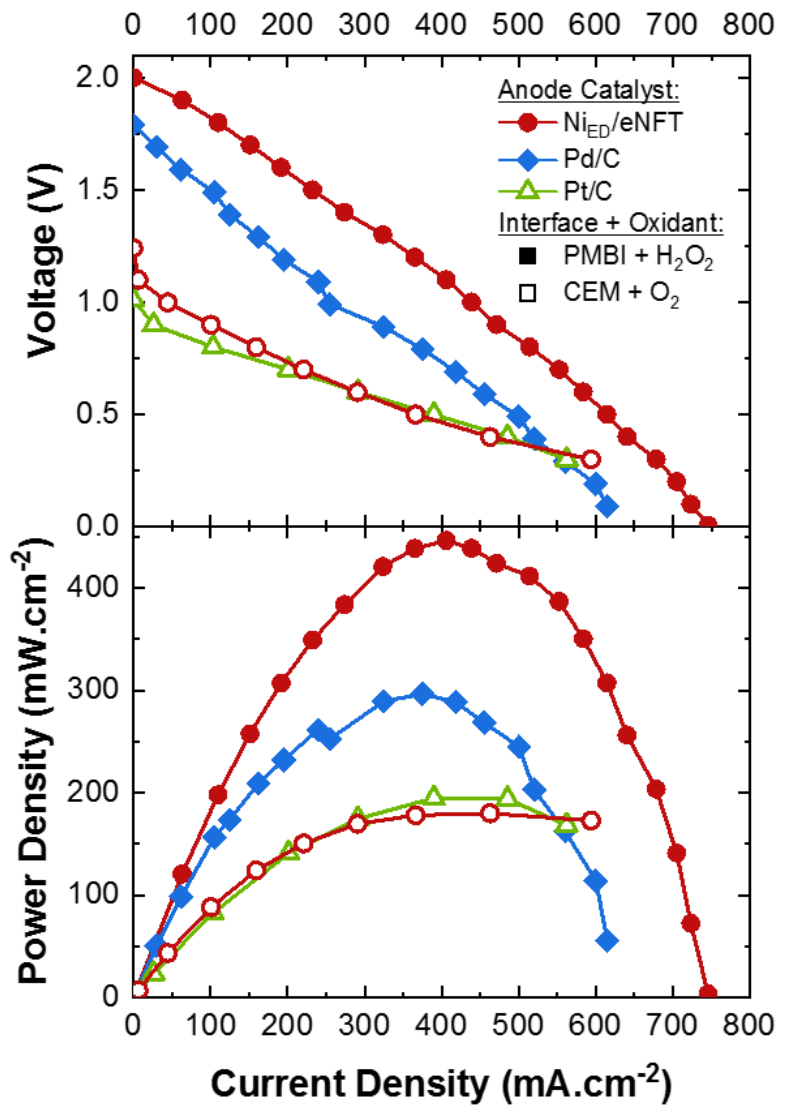

Figure 4. $\mathrm{DBFC}$ performance of $\mathrm{Ni}_{\mathrm{ED}} / \mathrm{eNFT}$ anodes used in two different configurations: $\mathrm{PMBI}$ separator $+\mathrm{H}_{2} \mathrm{O}_{2}$ oxidant at $T=70^{\circ} \mathrm{C}$ compared to $\mathrm{Pd}$ anode (full symbols), $\mathrm{CEM}$ and $\mathrm{O}_{2}$ oxidant at $T=60^{\circ} \mathrm{C}$ compared to Pt anode (hollow symbols) Commercial Pt/C electrodes $\left(1 \mathrm{mg} . \mathrm{cm}^{-2}\right)$ are used at the cathodes in all configurations. $\mathrm{Pd} / \mathrm{C}$ data was reproduced from Ref. ${ }^{27}$ with permission from Nature-Springer and $\mathrm{CEM}+\mathrm{O}_{2}$ data was reproduced from Ref. ${ }^{40}$ with the permission from Wiley.

\section{Conclusion}

In this study, we take advantage of the use of electrodeposited metallic nickel as an effective and cheap catalyst to increase the BOR activity at high cell voltage, an open 3D stand-alone electrode structure brought by a $\mathrm{Ni}$ felt to favour mass-transfer of reactants/products, and of a $\mathrm{pH}$-gradient-enabled microscale bipolar interface (PMBI) to efficiently separate the anolyte and catholyte compartments of a $\mathrm{BH}_{4}^{-} / \mathrm{H}_{2} \mathrm{O}_{2}$ fed DBFC. This unique combination enables to reach unprecedented performance: OCV (2.0 V) and peak power density $\left(446 \mathrm{~mW} . \mathrm{cm}^{-2}\right)$ for a $\mathrm{BH}_{4}-/ \mathrm{H}_{2} \mathrm{O}_{2}$ fed DBFC. The use of the anion-exchange ionomer at the anode deposited in a tailored procedure proved to be effective to protect the metallic $\mathrm{Ni}_{\mathrm{ED}} / \mathrm{eNFT}$ anode towards extensive and irreversible oxidation, while the $\mathrm{Ni}_{\mathrm{ED}} / \mathrm{eNFT}$ anode structure/composition maintained its promises in practical $\mathrm{BH}_{4}^{-} / \mathrm{H}_{2} \mathrm{O}_{2}$ fed DBFC compared to model 3-electrode cell measurements. This work opens the way to high-performance nonPGM based $\mathrm{BH}_{4}-1 \mathrm{H}_{2} \mathrm{O}_{2}$ fed DBFC, for portable applications.

\section{Data availability.}

The data that support the plots within this paper and other findings of this study are available from the corresponding authors upon reasonable request.

\section{Acknowledgements}

This work has been performed in the frame of the MobiDiC project, funded by the French National Research Agency (ANR, grant \# ANR16-CE05-0009-01). The authors express their gratitude to R. Martin, T. Encinas, for their support in SEM, EDS, XRD characterization and to Prof. Deckel's group for providing $\mathrm{Ni} / \mathrm{C}$ catalysts.

A.O. acknowledges the financial support from the RSF project No. 1873- 00143, funded by the Russian Science Foundation.

Z.W., S.S. and V.R. would like to acknowledge with gratitude the Office of Naval Research (ONR grant number N00014-16-1-2833) for funding their portion of this work. V.R. acknowledges with gratitude generous support from the Roma B. and Raymond $\mathrm{H}$. Wittcoff Distinguished University Professorship.

MC and GB thank Elena Davydova and Dario R. Dekel (Technion, Haifa, Israel) for having gently provided the $\mathrm{Ni} / \mathrm{C}$ catalyst used as benchmark in Fig. 2.

\section{Author contributions}

$G B$ and $M C$ had the original idea of the study and planned the experiments; $E S, A B$ and VR also contributed to the experiments' planning. GB made most of the experiments, data analysis (with $M C$ ) and drafted the first version of the paper. $\mathrm{ZW}$ and SS contributed to the DBFC $\left(\mathrm{BH}_{4}^{-} / \mathrm{H}_{2} \mathrm{O}_{2}\right)$ tests. AO contributed to the preparation of the $\mathrm{Ni}_{E D}$ samples. All authors contributed to the manuscript revision. $\mathrm{MC}$ and $G B$ prepared the final version of the article.

\section{Conflicts of interest}

The authors have no conflicts of interest to declare.

\section{References}

1. Li, Z. P., Liu, B. H., Arai, K., Asaba, K. \& Suda, S. Evaluation of alkaline borohydride solutions as the fuel for fuel cell. $J$. 
Power Sources 126, 28-33 (2004)

2. Park, K. T., Jung, U. H., Jeong, S. U. \& Kim, S. H. Influence of anode diffusion layer properties on performance of direct borohydride fuel cell. J. Power Sources 162, 192-197 (2006).

3. Miley, G. H. et al. Direct $\mathrm{NaBH} 4 / \mathrm{H} 2 \mathrm{O} 2$ fuel cells. J. Power Sources 165, 509-516 (2007).

4. Demirci, U. B. Direct liquid-feed fuel cells: Thermodynamic and environmental concerns. J. Power Sources 169, 239246 (2007).

5. Molina Concha, B. \& Chatenet, M. Direct oxidation of sodium borohydride on $\mathrm{Pt}, \mathrm{Ag}$ and alloyed $\mathrm{Pt}-\mathrm{Ag}$ electrodes in basic media. Part II. Carbon-supported nanoparticles. Electrochim. Acta 54, 6130-6139 (2009).

6. Urian, R. C. Air Independent Fuel Cells Utilizing Borohydride and Hydrogen Peroxide. Mater. Res. Soc. Symp. Proc. Vol. 1213, (2010).

7. Liu, B. H. \& Li, Z. P. Current status and progress of direct borohydride fuel cell technology development. J. Power Sources 187, 291-297 (2009).

8. Ma, J., Choudhury, N. A. \& Sahai, Y. A comprehensive review of direct borohydride fuel cells. Renewable and Sustainable Energy Reviews 14, 183-199 (2010).

9. Choudhury, N. A., Raman, R. K., Sampath, S. \& Shukla, A. K. An alkaline direct borohydride fuel cell with hydrogen peroxide as oxidant. J. Power Sources 143, 1-8 (2005).

10. Cao, D., Gao, Y., Wang, G., Miao, R. \& Liu, Y. A direct $\mathrm{NaBH} 4-\mathrm{H} 2 \mathrm{O} 2$ fuel cell using $\mathrm{Ni}$ foam supported $\mathrm{Au}$ nanoparticles as electrodes. Int. J. Hydrogen Energy 35, 807-813 (2010).

11. Haijun, W., Cheng, W., Zhixiang, L. \& Zongqiang, M. Influence of operation conditions on direct $\mathrm{NaBH} 4 / \mathrm{H} 2 \mathrm{O} 2$ fuel cell performance. Int. J. Hydrogen Energy 35, 26482651 (2010).

12. Oh, T. H. Design specifications of direct borohydridehydrogen peroxide fuel cell system for space missions. Aerosp. Sci. Technol. 58, 511-517 (2016).

13. Andrieux, J. et al. Spontaneous hydrolysis of sodium borohydride in harsh conditions. Int. J. Hydrogen Energy 36, 224-233 (2011).

14. Demirci, U. B. et al. Sodium Borohydride Hydrolysis as Hydrogen Generator: Issues, State of the Art and Applicability Upstream from a Fuel Cell. Fuel Cells 10, 335350 (2010).

15. Yamada, K. et al. Investigation of PEM type direct hydrazine fuel cell. J. Power Sources 115, 236-242 (2003).

16. Duteanu, N., Vlachogiannopoulos, G., Shivhare, M. R., Yu, E. H. \& Scott, K. A parametric study of a platinum ruthenium anode in a direct borohydride fuel cell. J. Appl. Electrochem. 37, 1085-1091 (2007).

17. Coowar, F. A., Vitins, G., Mepsted, G. O., Waring, S. C. \& Horsfall, J. A. Electrochemical oxidation of borohydride at nano-gold-based electrodes: Application in direct borohydride fuel cells. J. Power Sources 175, 317-324 (2008).

18. Qu, C., Zhang, H., Zhang, F. \& Liu, B. A high-performance anion exchange membrane based on bi-guanidinium bridged polysilsesquioxane for alkaline fuel cell application. J. Mater. Chem. 22, 8203-8207 (2012).

19. Wang, Z., Parrondo, J. \& Ramani, V. Anion Exchange Membranes Based on Polystyrene- Block -Poly(ethyleneran -butylene)- Block -Polystyrene Triblock Copolymers: Cation Stability and Fuel Cell Performance .J. Electrochem. Soc. 164, F1216-F1225 (2017).

20. Simons, R. Preparation of a high performance bipolar membrane. J. Memb. Sci. 78, 13-23 (1993).

21. Bazinet, L., Lamarche, F. \& Ippersiel, D. Bipolar-membrane electrodialysis: Applications of electrodialysis in the food industry. Trends Food Sci. Technol. 9, 107-113 (1998).

22. $\mathrm{Xu}, \mathrm{T}$. Development of bipolar membrane-based processes. Desalination 140, 247-258 (2001).

23. Dai, J. et al. A sandwiched bipolar membrane for all vanadium redox flow battery with high coulombic efficiency. Polymer (Guildf). 140, 233-239 (2018).

24. de León, C. P. et al. A direct borohydride-Acid peroxide fuel cell. J. Power Sources 164, 441-448 (2007).

25. Reeve, R. W. A Sodium Borohydride-Hydrogen Peroxide Fuel Cell Employing a Bipolar Membrane Electrolyte. Fuel Cell Semin. 2011 42, 117-129 (2012).

26. Arges, C. G., Prabhakaran, V., Wang, L. \& Ramani, V. Bipolar polymer electrolyte interfaces for hydrogen-oxygen and direct borohydride fuel cells. Int. J. Hydrogen Energy 39, 14312-14321 (2014).

27. Wang, Z., Parrondo, J., He, C., Sankarasubramanian, S. \& Ramani, $\mathrm{V}$. Efficient $\mathrm{pH}$-gradient-enabled microscale bipolar interfaces in direct borohydride fuel cells. Nat Energy 4, 281-289 (2019).

28. Vesborg, P. C. K. \& Jaramillo, T. F. Addressing the terawatt challenge: Scalability in the supply of chemical elements for renewable energy. RSC Advances 2, 7933-7947 (2012).

29. Oshchepkov, A. G. et al. Nickel Metal Nanoparticles as Anode Electrocatalysts for Highly Efficient Direct Borohydride Fuel Cells. ACS Catal. 9, 8520-8528 (2019).

30. Ma, X. et al. Facile fabrication of gold coated nickel nanoarrays and its excellent catalytic performance towards sodium borohydride electro-oxidation. Appl. Surf. Sci. 414, 353-360 (2017). 
31. Li, S., Shu, C., Chen, Y. \& Wang, L. A new application of nickel-boron amorphous alloy nanoparticles: anodecatalyzed direct borohydride fuel cell. lonics (Kiel). 24, 201209 (2018).

32. Zhang, D. et al. Three-dimensional functionalized graphene networks modified Ni foam based gold electrode for sodium borohydride electrooxidation. Int. J. Hydrogen Energy 41, 11593-11598 (2016).

33. Hua Dong et al. Electrooxidation mechanisms and discharge characteristics of borohydride on different catalytic metal surfaces. J. Phys. Chem. B 109, 1089610901 (2005).

34. Geng, X., Zhang, H., Ye, W., Ma, Y. \& Zhong, H. Ni-Pt/C as anode electrocatalyst for a direct borohydride fuel cell. J. Power Sources 185, 627-632 (2008).

35. Zhang, D. et al. Nickel particles supported on multi-walled carbon nanotubes modified sponge for sodium borohydride electrooxidation. Electrochem. commun. 35, 128-130 (2013).

36. Oshchepkov, A. G. et al. Exploring the Influence of the Nickel Oxide Species on the Kinetics of Hydrogen Electrode Reactions in Alkaline Media. Top. Catal. 59, 1319-1331 (2016).

37. Oshchepkov, A. G., Bonnefont, A., Parmon, V. N. \& Savinova, E. R. On the effect of temperature and surface oxidation on the kinetics of hydrogen electrode reactions on nickel in alkaline media. Electrochim. Acta 269, 111-118 (2018).

38. Oshchepkov, A. G., Bonnefont, A. \& Savinova, E. R. On the Influence of the Extent of Oxidation on the Kinetics of the Hydrogen Electrode Reactions on Polycrystalline Nickel. Electrocatalysis 11, 133-142 (2020).

39. Olu, P. Y., Deschamps, F., Caldarella, G., Chatenet, M. \& Job, N. Investigation of platinum and palladium as potential anodic catalysts for direct borohydride and ammonia borane fuel cells. J. Power Sources 297, 492-503 (2015).

40. Braesch, G. et al. Nickel 3D Structures Enhanced by Electrodeposition of Nickel Nanoparticles as High Performance Anodes for Direct Borohydride Fuel Cells. ChemElectroChem 7, 1789-1799 (2020).

41. Mayrhofer, K. J. J., Crampton, A. S., Wiberg, G. K. H. \& Arenz, M. Analysis of the Impact of Individual Glass Constituents on Electrocatalysis on Pt Electrodes in Alkaline Solution. J. Electrochem. Soc. 155, P78 (2008).

42. Grdeń, M., Alsabet, M. \& Jerkiewicz, G. Surface Science and Electrochemical Analysis of Nickel Foams. ACS Appl. Mater. Interfaces 4, 3012-3021 (2012).

43. Grdeń, M. \& Jerkiewicz, G. Influence of Surface Treatment on the Kinetics of the Hydrogen Evolution Reaction on Bulk and Porous Nickel Materials. Electrocatalysis 10, 173-183
(2019)

44. Wang, Z., Sankarasubramanian, S. \& Ramani, V. ReactantTransport Engineering Approach to High-Power Direct Borohydride Fuel Cells. Cell Reports Phys. Sci. 1, 100084 (2020).

45. Zadick, A., Dubau, L., Sergent, N., Berthomé, G. \& Chatenet, $\mathrm{M}$. Huge Instability of Pt/C Catalysts in Alkaline Medium. ACS Catal. 5, 4819-4824 (2015).

46. Lafforgue, C., Zadick, A., Dubau, L., Maillard, F. \& Chatenet, M. Selected Review of the Degradation of Pt and Pd-based Carbon-supported Electrocatalysts for Alkaline Fuel Cells: Towards Mechanisms of Degradation. Fuel Cells 18, 229238 (2018)

47. Lafforgue, C., Chatenet, M., Dubau, L. \& Dekel, D. R. Accelerated Stress Test of Pt/C Nanoparticles in an Interface with an Anion-Exchange Membrane - An Identical-Location Transmission Electron Microscopy Study. ACS Catal. 8, (2018).

48. Machado, S. A. S. \& Avaca, L. A. The hydrogen evolution reaction on nickel surfaces stabilized by $\mathrm{H}$-absorption. Electrochim. Acta 39, 1385-1391 (1994).

49. Oshchepkov, A. G. et al. On the effect of $\mathrm{Cu}$ on the activity of carbon supported Ni nanoparticles for hydrogen electrode reactions in alkaline medium. Top. Catal. 58, 1181-1192 (2015)

50. Davydova, E. S., Speck, F. D., Paul, M. T. Y., Dekel, D. R. \& Cherevko, S. Stability Limits of Ni-Based Hydrogen Oxidation Electrocatalysts for Anion Exchange Membrane Fuel Cells. ACS Catal. 9, 6837-6845 (2019).

51. Rostamikia, G. \& Janik, M. J. Direct borohydride oxidation: mechanism determination and design of alloy catalysts guided by density functional theory. Energy Environ. Sci. 3 1262 (2010).

52. Rostamikia, G. \& Janik, M. J. First principles mechanistic study of borohydride oxidation over the Pt(1 111 ) surface. Electrochim. Acta 55, 1175-1183 (2010).

53. Olu, P.-Y. et al. Influence of the concentration of borohydride towards hydrogen production and escape for borohydride oxidation reaction on Pt and Au electrodes experimental and modelling insights. J. Power Sources 375, 300-309 (2018).

54. Finkelstein, D. A. et al. Self-Poisoning during BH 4 Oxidation at $\mathrm{Pt}$ and $\mathrm{Au}$, and in Situ Poison Removal Procedures for BH 4 - Fuel Cells. J. Phys. Chem. C 117, 1571-1581 (2013)

55. Braesch, G., Bonnefont, A., Martin, V., Savinova, E. R. \& Chatenet, $M$. Borohydride oxidation reaction mechanisms and poisoning effects on $\mathrm{Au}, \mathrm{Pt}$ and $\mathrm{Pd}$ bulk electrodes: From model (low) to direct borohydride fuel cell operating (high) concentrations. Electrochim. Acta 273, 483-494 (2018). 
56. Wang, Z. et al. Influence of Water Transport across

Microscale Bipolar Interfaces on the Performance of Direct Borohydride Fuel Cells. ACS Appl. Energy Mater. 3, 44494456 (2020).

57. Hjelm, R. M. E. et al. Impact of the Anode Catalyst Layer Design on the Performance of $\mathrm{H} 2 \mathrm{O} 2$-Direct Borohydride Fuel Cells. J. Electrochem. Soc. 166, F1218-F1228 (2019).

58. Chatenet, M. Tailoring membranes. Nat. Energy 4, 261-262 (2019). 